Горбачова О. М., к.е.н., доцент

Національний авіаційний університет м. Київ, Украӥна

DOI: https://doi.org/10.30525/978-9934-26-068-1-10

\title{
ЕКОНОМІКО-ОРГАНІЗАЦІЙНИЙ МЕХАНІЗМ ФІНАНСУВАННЯ ТА ЙОГО РОЛЬ У РОЗВИТКУ АЕРОПОРТОВИХ КОМПЛЕКСІВ
}

Створення ефективної системи фінансування аеропорту $\epsilon$ однією $з$ основних умов ефективності управління їх життєвим циклом. Без вирішення питань фінансування неможливо успішно провести реструктуризацію i реформування, а головне, оздоровити економіку і привести до подальшого економічного розвитку аеропортів в умовах ринку. 
Більшість українських аеропортів вимагає реконструкції i модернізації інфраструктури, збільшення виробничих потужностей будівель i споруд аеродрому i службово-технічної території (СТT). Для реалізації цих вимог необхідні значні капіталовкладення, тобто створення і використання ефективної системи фінансування.

Враховуючи необхідність залучення великого обсягу інвестицій, тривалий термін їх окупності та загальнодержавне значення, передбачено розбудову та реконструкцію інфраструктури аеропортів здійснювати за рахунок державного та місцевих бюджетів із створенням сприятливих умов для недержавних інвесторів. Держава, вкладаючи кошти в розвиток інфраструктури суспільно значущих аеропортів України, залишає за собою важелі контролю за ефективністю їх використання шляхом створення на базі аеропортів акціонерних товариств 3 державним пакетом акцій, розмір якого визначається сумою вкладених коштів.

Державна політика розвитку авіаційного транспорту полягає у формуванні та реалізації державного механізму регулювання діяльності аеропортів, розробці перспективних планів їх розвитку iз залученням недержавних інвестицій, недопущенні приватизації злітно-посадкових смуг. У той же час система фінансування аеропортів включає різні види і форми фінансування. Основними видами є власні, державні, позикові та інвестиційні кошти. Склад системи фінансування аеропортів наведено на рис. 1.

Використання конкретних видів i форм фінансування залежить, в першу чергу, від організаційно правової системи аеропорту (табл. 1).

ДВП - інститут державного i приватного партнерства, заснований на приватному та державному секторах управління аеропорту. При державній формі власності розраховувати на кошти інвесторів або виключно на кошти державного інвестора не доводиться. У цьому випадку основними засобами $є$ власні або позикові кошти. 


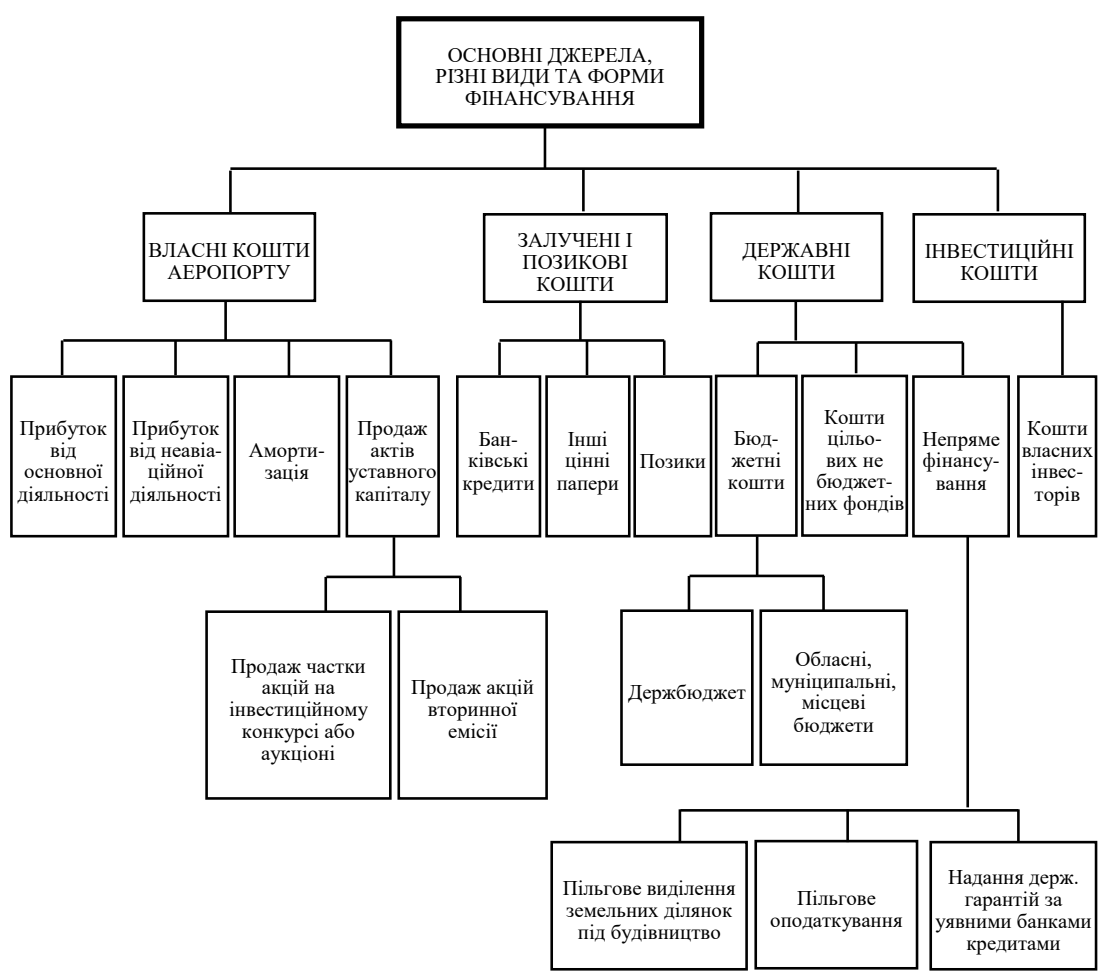

Рис. 1. Система фінансування аеропортів

Знаходження аеропорту у приватній власності підвищує можливість залучення інвесторів. Одного джерела фінансування, як правило, недостатньо. Для реалізації програми реформування розвитку аеропорту необхідно залучення різних джерел - це i інвестори, і позикові кошти, і бюджетні кошти, однак в цьому випадку буде ефективно вкладення і власних коштів для успішної реалізації програми розвитку аеропорту.

Аеропорт складається 3 великої кількості різних виробничих комплексів, які мають певний рівень значущості для функціонування аеропорту в цілому, а також різний рівень технічної оснащеності. У зв'язку з цим при фінансуванні програм розвитку аеропорту необхідний диференційований підхід до капіталовкладень в ті або інші структури аеропорту. 
Види й форми фінансування аеропортів
при різній організаційно-правовій системі

\begin{tabular}{|c|c|c|c|c|c|c|}
\hline \multirow{3}{*}{$\begin{array}{c}\text { Організаційно-правова } \\
\text { система аеропорту }\end{array}$} & \multicolumn{6}{|c|}{ Форма (вид) фінансування } \\
\hline & 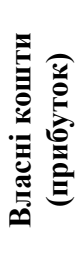 & 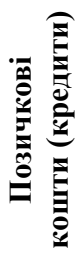 & 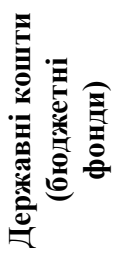 & 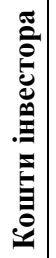 & 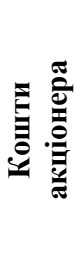 & 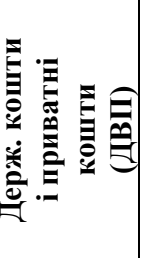 \\
\hline & 1 & 2 & 3 & 4 & 5 & 6 \\
\hline $\begin{array}{c}\text { Державне унітарне } \\
\text { підприємство (ДУП) } \\
3 \text { часткою держвласності 51\% }\end{array}$ & + & + & $\begin{array}{l}+ \\
-\end{array}$ & - & - & - \\
\hline $\begin{array}{c}\text { Публічне акціонерне } \\
\text { товариство (ПАТ) }\end{array}$ & + & + & - & - & + & - \\
\hline $\begin{array}{c}\text { ДУП з часткою власності 5\% } \\
\text { і більше }\end{array}$ & + & + & $\begin{array}{l}+ \\
- \\
-\end{array}$ & $\begin{array}{l}- \\
+ \\
\end{array}$ & - & $\begin{array}{ll}+ \\
- \\
-\end{array}$ \\
\hline Приватна власність & + & + & - & + & - & - \\
\hline
\end{tabular}

Аналіз існуючого стану виробничих комплексів, об'єктів i споруд аеропортів визначає приблизний розподіл капітальних вкладень наступним чином (табл. 2).

Таблиця 2

Приблизний розподіл капітальних вкладень

\begin{tabular}{|c|c|c|}
\hline $\begin{array}{c}\text { Виробничі комплекси } \\
\text { та споруди аеропорту }\end{array}$ & $\begin{array}{c}\text { Капітальні } \\
\text { вкладення,\% }\end{array}$ & $\begin{array}{c}\text { Форма фінансування } \\
\text { (табл. 1) }\end{array}$ \\
\hline Аеропортові споруди & 24 & $1,2,3,6$ \\
\hline $\begin{array}{c}\text { Пасажирський та вантажний } \\
\text { комплекси (термінали) }\end{array}$ & 37 & $1-6$ \\
\hline $\begin{array}{c}\text { Об’єкти технічного } \\
\text { обслуговування повітряних суден } \\
\text { (ангари) }\end{array}$ & 7 & $1,2,4,5$ \\
\hline $\begin{array}{c}\text { Об'єкти авіа паливо-забезпечення } \\
\text { (склади паливно-мастильних } \\
\text { матеріалів (ПММ)) }\end{array}$ & 7 & $1-6$ \\
\hline $\begin{array}{c}\text { Об'єкти службово-технічної } \\
\text { території (СТТ) }\end{array}$ & 25 & 1,5 \\
\hline
\end{tabular}


Для формування програм розвитку аеропортів державного значення може бути створена спеціалізована форма фінансування, наприклад, банк, фонд розвитку (рис. 2).

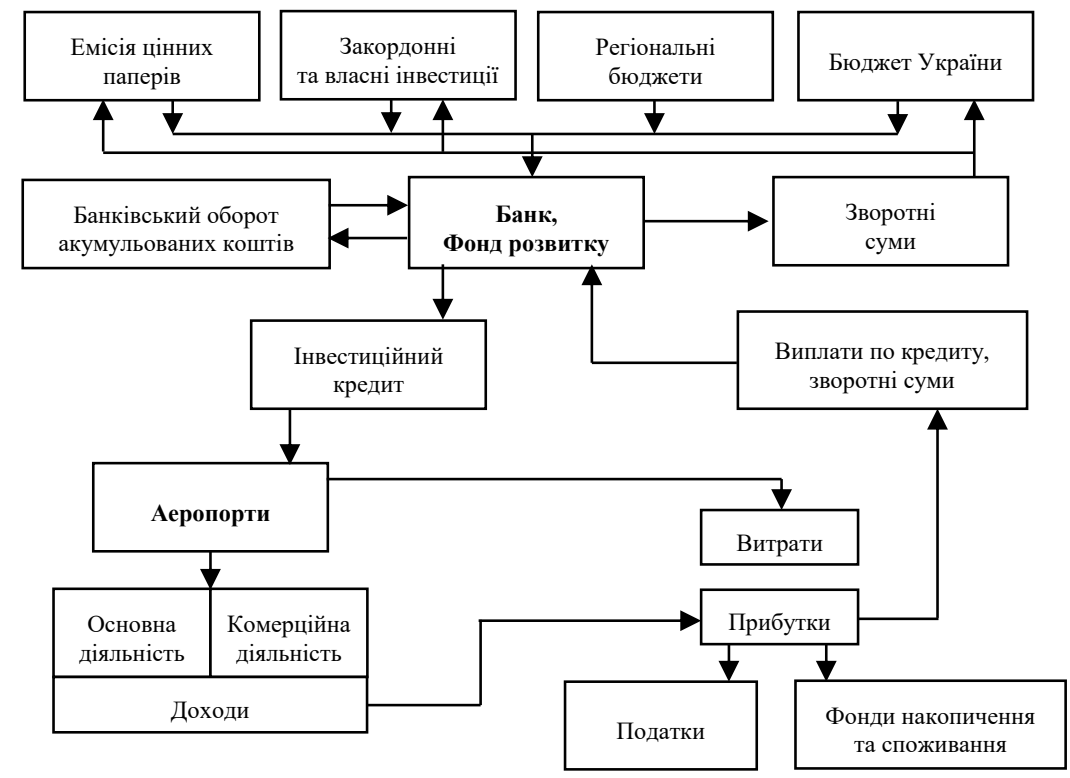

\section{Рис. 2. Принципова схема фінансування аеропортової діяльності}

Джерело: складено автором

У більшості країн розвиток аеропортів здійснюється головним чином за рахунок самофінансування та національних бюджетних коштів.

Думку про те, що аеропорти потребують постійних асигнувань 3 бюджету i, отже, є певним тягарем для держави i місцевих властей, не повністю відповідає реальній дійсності. Згідно зі статистикою IКАО із збитками працюють не більше чверті всіх аеропортів світу. Крім того, показник чистого прибутку i рентабельності аеропортів світу майже вдвічі вище, ніж у авіакомпаній. Якщо середня норма прибутку авіакомпаній навіть у роки підйому не перевищувала $6,5-7 \%$, то у аеропортів цей 
показник досягав 10-12\%. Це свідчить про те, що при чіткій організації діяльності аеропортів і гарному менеджменті вони $є$ більш прибутковими, ніж авіакомпанії. Підстав тут багато, одна 3 них - менша схильність аеропортів до конкуренції, а в окремих випадках взагалі монопольне становище на місцевому та регіональному ринку. 